\title{
PENGARUH IMF TERHADAP KEBANGKITAN EKONOMI RUSIA PADA KEPEMIMPINAN VLADIMIR V. PUTIN TAHUN (2000-2008)
}

\author{
Theresia Devina \\ Universitas 17 Agustus 1945 Jakarta \\ Theresiadevina5@gmail.com
}

\begin{abstract}
Abstrak
Penulis menggunakan teori Ekonomi Politik untuk menganalisa hubungan IMF dan kebangkitan ekonomi Rusia. Teori ini dapat menjelaskan masalah kehidupan ekonomi yang diliputi oleh kontroversi dan ketidakpastian, dimana saat itu isu-isu dasar ekonomi-politik bermunculan, yaitu bagaimana hubungan antara negara dengan ekonomi dan antara ekonomi dan politik. Konsep ekonomi politik juga dapat terlihat dari hubungan IMF yang merupakan organisasi moneter internasional dengan negara Rusia dimana masalah ekonomi yang menjadi dasar dari kerjasama mereka, namun ada kepentingan politik yang diperjuangkan oleh kedua pihak. Kepemimpinan

Vladimir V. Putin menjadi pertimbangan lain bahwa konsep ekonomi politik tidak dapat dipisahkan dalam proses kebangkitan ekonomi Rusia, karena kebangkitan ekonomi Rusia dapat berjalan karena kebijakan-kebijakan politik presiden Vladimir

V. Putin. Penelitian ini diharapkan dapat memberi gambaran proses kebangkitan ekonomi Rusia yang terjadi dalam waktu delapan tahun. Pembaca dapat mempelajari bahwa kebijakan pemerintah dan pelaku birokrasi yang nasionalis dapat membawa suatu negara keluar dari krisis besar. Pelunasan hutang Rusia terhadap IMF menjadi bukti nyata.
\end{abstract}

Kata Kunci : Ekonomi Politik, IMF, Rusia, Vladimir V. Putin

\section{Pendahuluan}

Rusia merupakan negara yang terkenal di dunia saat ini serta diakui kekuatan ekonomi dan militernya, namun Rusia pernah mengalami krisis ekonomi yang begitu mengenaskan, negara dengan angka kemiskinan yang cukup besar, pertumbuhan Produk Domestic Bruto (PDB) yang pernah mencapai angka (-19 persen) pada tahun 1992. Bahkan tentara Rusia pernah menerima sayur mayur sebagai gaji mereka.

Keterpurukan ekonomi Rusia itu di karenakan cadangan kas negara yang minim serta warisan utang dari Uni Soviet ( Rusia merupakan negara pecahan Uni Soviet yang dibebankan hutang luar negeri oleh Uni Soviet, setelah runtuhnya negara tersebut). Hal lain yang menyebabkan masalah ekonomi di Rusia ternayata tidak berbeda jauh dari negara-negara Asia 
yaitu Resep Internsional Monetary Fund (IMF). Resep IMF ini diduga menjadi penyebab paling berpengaruh terhadap krisis yang terjadi di Rusia pada tahun 1990-an. Bantuan-bantuan yang diberikan melalui IMF lebih banyak di korupsi oleh para pejabat pemerintahan dan pembisnis di Rusia. IMF merupakan lembaga moneter dunia yang bertujuan:“" menjamin atau mengamankan terselenggaranya kerjasama moneter internasional, menstabilitaskan nilai tukar mata uang serta memperluas likuiditas internasional untuk kepentingan perdagangan internasional dan penyedian lapangan kerja"1 Sedangkan yang dimaksud dengan resep IMF ialah "IMF secara unik memiliki posisi untuk mempengaruhi kebijakan nasional negara-negara yang terancam defisit neraca pembayaran"2 . Resep IMF inilah yang membawa Rusia pada kehancuran ekonominya. Joseph E. Stiglitz pakar ekonomi dunia, menyatakan bahwa," sama seperti di Asia kebijakan IMF dan departemen Keuangan AS turut berperan besar menjatuhkan Rusia.”3. Resep IMF untuk Rusia adalah memprioritaskan sistem ekonomi pasar (sistem ekonomi dimana pasar yang memiliki peran penting dalam menentukan kebijakan ekonomi suatu negara), perkembangan infrastuktur dan kelembagaan di Rusia diabaikan. Penerapan sistem ekonomi ini dilakukan secara cepat dan radikal, perubahan sistem ekonomi yang berjalan, membuka jalan bagi para oligarki berkuasa untuk menguasai aset negara. Jalan uang masuk dan keluar di Rusia terjadi dalam tempo yang cepat dengan kemungkinan oligarki melakukan korupsi dan mentransfer uangnya untuk bisnis di luar Rusia sangat besar. "Pelajaran dari negara-negara yang sebelumnya mengalami krisis memperlihatkan bahwa arus masuk modal asing hanya akan terjadi atau bertahan disuatu negara jika reformasi ekonomi juga berhasil, lengkap dengan keberadaan perlindungan hukum atas hak milik, keberadaan birokrasi yang kukuh dan hukum yang ditegakkan" Kehancuran perekonomian Rusia juga diakibatkan oleh korupsi dan perilaku para pejabat yang sudah memutarbalikan fungsi-fungsi lembaga negara. Hal itu terungkap pada masalah skandal Finance Investment management Company (Fimaco). Dalam kasus ini di kabarkan bahwa anggota pemerintahan dan mantan anggota pemerintahan Presiden Boris Yeltsin yang saat itu berkuasa turut terlibat didalamnya.

\footnotetext{
${ }^{1}$ Robet A.Isaak, Ekonomi politik Internasional, PT Tiara Wancana Yogya, Yogyakarta,1995 hal.60.

${ }^{2}$ Ibid., hal. 61.

${ }^{3}$ Simon Saragih, Bangkitnya Rusia, Kompas Media Nusantara, Jakarta, 2008, hal. 11.

${ }^{4}$ Ibid., hal 14.
} 
Skandal Fimaco ${ }^{5}$ yang menelan dana pinjaman Rusia dari IMF dan kreditor internasional lainnya tidak membuat IMF bertindak tegas, hal yang sangat mengejutkan IMF bahkan memberikan pinjaman lagi, hal ini menimbulkan dugaan bahwa IMF juga terlibat dalam kasus skandal Fimaco. Karena selama bantuan IMF mengalir ke Rusia, IMF memiliki tim pemantau jalannya pembagunan ekonomi negara yang dibantunya. IMF seharusnya menyadari ada kekeliruan dari Skandal Fimaco.

Pada Desember 1999 Presiden Yeltsin mundur dan mengumumkan pemilu dini yang diadakan pada tahun 2000, pemilu itu memenangkan Vladimir V. Putin sebagai presiden baru Rusia. Vladimir V. Putin merupakan mantan anggota dinas rahasia dan informasi atau peneranggan Rusia Komite Gosudarstvennoy Bezopasnosti (KGB). Ia memiliki jiwa nasionalisme yang kuat dan sangat membenci oligarki yang melakukan perampokan terhadap Negara Rusia. Bersama Eks-KGB lainnya yang telah berganti nama menjadi Federalnaya Sluzhba Bezopasnosti (FSB) dan dikenal dengan sebutan Siloviki. Vladimir V. Putin melakukan pemaksaan pengembalian aset-aset negara dari para oligarki yang melakukan perampokan kepada negara. Sikap Putin memang bertentangan dengan resep yang diajukan IMF untuk Rusia. Vladimir V. Putin mengatakan ia memilih ekonomi pasar sebagai sistem ekonomi untuk membagun kembali Rusia, namun harus disesuaikan dengan kondisi di Rusia. Ia menyatakan bahwa Rusia bisa meraih masa depan dan mengelola negara dengan kombinasi antara prinsip ekonomi pasar dan demokrasi yang sesuai dengan realitas di Rusia. Presiden Vladimir V. Putin membuktikan perkataannya dengan kebijakan-kebijakannya yang nasionalis, dimana setiap tindakan ekonomi bertujuan untuk kesejahteraan bangsa, setiap tindakan ekonomi yang merugikan negara akan di bubarkan serta asetnya di ambil oleh negara.

Saat bertemu Presiden Vladimir V. Putin pada Agustus 2000 Bill Clinton, mantan presiden Amerika Serikat menyatakan bahwa, Vladimir V. Putin adalah orang yang mampu melahirkan Rusia yang kuat dan makmur. Mikhail Gorbachev juga mengatakan bahwa Putin bukanlah ancaman bagi Demokrasi di Rusia. ${ }^{6}$ Sikap pemerintahan Vladimir V. Putin yang tegas

\footnotetext{
${ }^{5}$ Fimaco merupakan lembaga keuangan di Rusia yang didirikan pada tahun 1990-an dengan modal 1000 USD dan sebagian sahamnya di miliki oleh Bank sentral Rusia, namun basis dari lembaga keuangan ini terletak di kota Jesrey, Channel Island, Inggris.

${ }^{6}$ Ibid., hal.107.
} 
dan banyak terlibatnya anggota eks-KGB tidak di pandang sebagai ancaman jalannya sistem demokrasi di Rusia. Mengamati pertumbuhan Ekonomi Rusia saat ini memang sangat menarik. Hal itu disebabkan Negara Rusia yang merupakan pecahan dari Uni Soviet yang terkenal dengan kekuatan militer, namun lemah dalam perekonomiannya. Sekarang kita dibuat tercengang oleh perkembangan ekonomi yang terjadi di Rusia, angka kemiskinan dan pengangguran menurun secara cepat, hutang luar negeri yang dapat terbayar serta PDB yang terus meningkat.

Kekuatan ekonomi Rusia menjadi sesuatu yang berpengaruh dalam study hubungan Internasional saat ini, terutama dengan munculnya organisasi BRICs ( Brasil, Rusia, India, China dan South Africa) yang kreteria anggotanya adalah negara dengan pertumbuhan ekonomi terbesar di dunia saat ini. BRICs diyakini dapat menandingi organisasi Goverment eight (G8) yang merupakan gabungan negara-negara maju dengan tingkat PDB yang tinggi. Saat ini Rusia merupakan negara yang cukup berpengaruh dalam organisasi BRICs. Dengan demikian dunia telah menyadari bahwa Rusia telah menjadi negara yang memiliki kekuatan ekonomi yang harus diperhitungkan dalam perkembangan ekonomi internasional.

Perkembangan ekonomi Rusia bukan hanya memberi pengaruh pada perekonomian dunia saja , tapi juga memberikan dampak pada sistem pertahanan dan keamanan dunia. Saat Amerika Serikat (AS) menyatakan ingin melakukan Invasi ke Irak, Rusia menggunakan hak vetonya untuk melakukan penolakan terhadap niat AS tersebut, walaupun pada akhirnya AS tetap melakukan invasi ke Irak. Dalam hal lain Rusiaa merupakan negara yang mendukung pengembangan senjata nuklir di Iran yang sangat ditentang oleh negara Amerika Serikat. Sampai saat ini kekuatan militer Rusia masih diakui oleh dunia, terlebih lagi Rusia adalah produsen senjata-senjata perang yang berteknologi tinggi, kapal-kapal selam maupun pesawat tempur merupakan beberapa hasil industri yang banyak di minati oleh pasar dunia. Rusia juga memiliki sumber daya alam yang melimpah terutama minyak bumi, gas alam dan pertanian yang menjadi penyumbang devisa negara.

\section{Pembahasan}

Pada umumnya sistem perekonominan suatu negara akan terpolarisasi menjadi ekonomi nasionalis (pendekatan terpusat ke negara) dimana setiap komponen ekonomi diatur oleh negara dan ekonomi liberal (kebebasan pasar). Kedua system ini biasanya dipakai saling 
berganti atau stati tergantung pemerintahan yang berlangsung serta dapat juga di pengaruhi oleh system ekonomi internasional yang sedang berlangsung.

\section{A. Polarisasi Ekonomi}

\section{Ekonomi Terpusat ke Negara}

Sistem ekonomi nasionalis atau sosialis merupakan sistem ekonomi yeng terpusat ke negara, sistem ini dijalankan oleh Unisoviet saat Stalin berkuasa di negara tersebut. Sistem ekonomi ini memberikan kekuasaan penuh kepada Negara (pemerintahnya) dalam mengatur jalannya perekonomian negara. Pada masa Stalin sikap pemimpin yang otoriter mempertegas bentuk dari sistem ekonomi sosialis yang paling ekstrim yaitu komunis.

Delianov menyatakan :"Soliaslisme dilihat sebagai suatu sistem ekonomi-politik adalah sebuah sistem yang dilandaskan pada prinsip komune atau kebersamaan, dimana pemilik alat-alat produksi (means of production) dan distribusi adalah bersifat kolektif. Dalam masyarakat sosialis yang menonjol adalah kebersamaan, dan salah satu bentuknya yang paling ekstrim adalah komunisme, dimana keputusan-keputusan ekonomi disusun, direncanakan, dan sekaligus dikontrol oleh negara.",

Sistem solisalis komunis yang dijalankan oleh Stalin merujuk pada konsep Marxisme dan Leninisme. Inti pokok dari paham Marxisme ini adalah pendekatanpendekatan secara mekanistik atau suprastruktur politik (sosial, ideologi, dan budaya) oleh suatu basis ekonomi. Marx juga menjelaskan lebih lanjut bahwa penentu dari segala bidang kehidupan yaitu politik, sosial, budaya, bahkan moral dan falsafah dan juga Ideologi adalah ekonomi. Pandangan Marx ini juga dikenal dengan paham materalistik. ${ }^{8}$

Pandangan Marx tentang negara ialah sebagai pelaksana kekuasaan dan wewenang, tetapi pengaruh yang sesunguhnya terletak diluar lembaga-lembaga negara yaitu materi. Negara berperan dalam meyiapkan kondisi-kondisi politik dan penagwasan yang penting dalam menjaga moda produksi dalam negeri. Negara merupakan aktor penting, karena negara yang memiliki komando dalam setiap kegiatan ekonomi yang berlangsung.

\footnotetext{
${ }^{7}$ Deliarnov, Op. CIt, hal. 39.

${ }^{8}$ Ibid., hal 44.
} 
Dalam ekonomi Komunis konsep negara bangsa atau nation-state menjadi peran sentral dalam setiap kegiatan pembagunan negara. Konsep negara bangsa adalah suatu gagasan yang didirikan oleh seluruh bangsa. Tujuan dari negara bangsa adalah kesejahteraan umum bagi semua masyarakat, dan semua kebijakan pemerintah harus bertujuan untuk kesejahteraan masyarkat Umum. ${ }^{9}$

Tujuan dari komunisme Marxisme dan Leninisme adalah ingin menciptakan tatanan masyarakat baru dengan ciri masyarakat tanpa kelas, tidak ada hak milik pribadi atas alat produksi dan semua itu diatur oleh negara yang sentralistik. Konsep Marx menjadi teori untuk merumuskan kebijakan sedangkan operasionalnya adalah pemikiran Lenin. ${ }^{10}$ Pengunaan konsep Marxisme dan Leninisme ini di sesuaikan oleh kondisi yang terjadi di Rusia pada masa kekepimpinan Stalin. Konsep tersebut merupakan ideologi pada masa pemerintahan Stalin yang melegitimasikan kekuasaan dengan membuat undang-undang yang memutuskan bahwa Marxisme-Leninisme sebagai ideologi negara. $^{11}$

Bentuk sistem ekonomi nasionalis kembali dijalankan di Rusia pada masa pemerintahan Presiden Putin, namun sistem ekonomi yang berjalan bentuknya tidak ekstrim seperti komunis. Pendekatan terpusat ke negara tetap dilakukan, namun pihak swasta diberi ruang untuk berkembang. Modal asing juga diijinkan masuk ke Rusia namun dengan ketentuan-ketentuan khusus.

Sistem ekonomi dengan pendekatan ke negara, akan melakukan fokus pembagunan industri sehingga tercipta kemandirian industri dan berkembang menuju pada kemandirian ekonomi. Pada pemerintahan Stalin, produksi industri senjata perang menjadi penyumbang terbesar devisa negara karena saat itu terjadi Perang Dingin. Namun terjadi ketimpangan dimana industri agrarian dan sector lain tidak mendapat perhatian oleh pemerintah, sehingga saat industri berat dan persenjataan perang mengalami kejatuhan tidak ada sektor industri lain yang dapat melakukan subsidi silang menahan krisis ekonomi yang terjadi di Unisoviet. Oleh karenanya kemandirian industri

\footnotetext{
${ }^{9}$ Nurcholish Majid, Indonesia Kita, Gramedia, Jakarta, 2004, hal 42-43.

${ }^{10}$ Alkatiri,Op. Cit., hal.52.

${ }^{11}$ Ibid.
} 
harus dilakukan disetiap sektor industri dalam pembagunan ekonomi agar setiap sektor industri dapat melakukan subsidi silang jika ada sektor yang mengalami kemunduran.

Dalam buku Megutamakan Rakyat, Mayor Jenderal TNI Saurip Kadi menyatakan “ kemandirian ekonomi hanya bisa dicapai apabila ada kebijakan yang jelas, jangka panjang dan konsisten, sehingga pelaku usaha dapat berpartisipasi secara aktif, terbuka, kompetitif dan tidak dirugikan." 12 Kemandirian ekonomi suatu bangsa akan meminimalkan ketergantungan negara pada negara lain atau pihak asing lainnya, bahkan dapat membuat negara dan pihak asing lainnya jadi tergantung pada negara tersebut. Hal ini menjadikan negara tersebut memiliki kedudukan dan peran yang sama dalam kancah internasional, sehingga negara tersebut memiliki power dan dapat memperjuangkan kepentingan nasionalnya di dunia Internasional.

\section{b. Ekonomi Pasar}

Sistem ekonomi pasar atau yang lebih dikenal dengan sistem liberal adalah sistem perekonomian yang menjadikan pasar sebagai pedoman dalam setiap kebijakan ekonomi yang akan dijalankan. Paham ini dikembangkan oleh Adam Smith. Menurut Adam Smith Pasar dengan tangan tidak kentaranya (Invisible hand) merupakan penggerak dalam setiap aktivitas ekonomi manusia. Pasar merupakan tempat mengalokasikan sumber daya alam. Arthur Sheldon dalam Capitalism (1991) yang dikutip oleh Deliarnov dalam buku Ekonomi Politik menyatakan ada empat tugas sistem-sistem ekonomi ${ }^{13}$ : (1) mengembangkan teknik-teknik untuk mengembangkan sumber-sumber yang langka, (2) membuat intensif untuk berkonsentrasi pada metode-metode paling produktif, (3) menyediakan alat-alat untuk merakit dan mendistribusikan informasi, (4) menciptakan prinsip-prinsip mengalokasikan output pada pengunaan yang paling penting atau bernilai paling tinggi. Metode dan alat-alat inilah yang dikembangkan dalam pasar. Sehingga dipasar terjadi persaingan baik antara produsen, jumlah barang yang diperjualkan, harga barang, maupun kualitas barang. Oleh karenanya dibutuhkan kreativitas dan inovasi untuk dapat bermain dipasar.

Adam Smith menyatakan bahwa campur tangan pemerintah yang terlalu banyak justru membawa perekonomian negara kepada inefisiensi. Dalam The Wealth of Nations Adam

\footnotetext{
${ }^{12}$ Saurip Kadi,Siok Lian Liem, Megutamakan Rakyat- Wawanara Mayor Jenderal TNI Saurip Kadi, Yayasan Obor Indonesia, 2008, hal. 331.

${ }^{13}$ Deliarnov, Op. Cit., hal 29.
} 
Smith menegaskan tugas negara sebagai berikut ${ }^{14}$ : (1) melindungi masyarakat dari kekerasan dan serbuan negara lain, (2) melindungi setiap warga dari tindakan ketidakadilan, pemerasan, penindasan dari warga lainnya, (3) mengadakan serta mempertahankan prasarana publik dan berbagai lembaga publik yang ada, bukan hanya untuk golongan atau orang-orang tertentu. Hal itu menyatakan bahwa negara hanya berfungsi sebagai pengawas jalannya perekonomian sedangkan berbagai kebijakan dan penyelesaian masalah ekonomi diserahkan kepada pasar. Pasar yang dengan sendirinya akan melakukan keseimbangan perekonomianan.

Sistem ekonomi pasarmulai berlaku di Uni Soviet pada masa pemerintahan Mikhail Gorbachev. Saat Gorbachev memimpin Unisoviet ia mecetuskan reformasi terhadap sistem ekonomi politik Unisoviet sebelumnya. Ada tiga gagasan dasar yang di kemukan oleh Gorbachev: Perestroika (Restrukturisasi), ini adalah konsep pembaharuan masyarakat Soviet, untuk mengatasi kekurangan-kekurangan yang telah terjadi dibidang ekonomi, politik dan Moral. Selanjutnya untuk mengerakan Perestroika dicetuskan Demokratiya (Demokrasi) dan Glasnost (Keterbukaan). Ketiga konsep itu membawa Rusia pada suatu pemerintahan yang lebih terbuka dan bebas. Kebijakan ini ditujukan untuk memperbaiki sistem ekonomi politik Unisoviet yang telah terpuruk dengan banyaknya gerakan-gerakan separatism yang melakukan perlawanan terhadap negara. Namun kebijakan Glasnots dan Perestroika yang dijalankan oleh pemerintaha Gorbachev ternyata membawa pengaruh terhadap semakin menguatnya gerakan separatis, akibat dari keterbukaan dan demokrasi yang menjadi inti kebijakan tersebut. ${ }^{15}$ Sampai akhirnya banyak terjadi kudeta yang menagkibatkan kondisi negara dalam keadaan darurat. Oleh karenanya kegiatan reformasi pada masa Gorbachev lebih banyak terfokus pada bidang politik sedang bidang ekonomi belum terasa perubahannya.

Semangat ekonomi liberal yang dimulai pada pemerintahan Gorbachev dilanjutkan oleh pemimpin Rusia pertama yaitu Boris Yeltsin. Sistem ekonomi liberal yang dijalankan oleh presiden Boris Yeltsin merupakan implementasi dari Washington Consensus. Hal itu dikarenakan pada saat pemerintahan presiden Boris Yeltsin ekonomi Rusia dalam keadaan Krisis dan presiden Boris Yeltsin mengambil kebijakan untuk melakukan pinjaman pada IMF.

\footnotetext{
14 Ibid., hal. 31

${ }^{15}$ Fahrurodji, Op. Cit.,
} 
Setiap negara yang melakukan pinjaman kepada IMF wajib menjalankan kesepakatan yang tertulis dalam LOI. Butir-butir kebijakan dalam LOI yang diberikan IMF oleh semua negara peminjam adalah sama yaitu sepuluh butir yang disepakati dalam Washington Consens, karena dasar dari kebijan IMF tidak akan berlawanan dengan kebijakan ekonomi Amerika Serikat dan Washington Consensus adalah perjanjian yang merumuskan kebijakan ekonomi yang harus dijalankan oleh kepala negara yang ingin mengatasi krisis ekonomi negaranya.

Washington Consensus adalah perjanjian yang dicapai IMF (International Monetary Fund), Bank Dunia (World Bank), dan Departemen Keuangan AS (US Treasury Department) pada akhir tahun 1990an. Washington Consensus berisikan 10 butir kebijakan yang dianggap tepat dalam mengatasi semua masalah pembagunan dan perkembangan pada negara-negara berkembang. Selanjutnya butir-butir dalam Washington consensus ini yang dijalankan oleh IMF dalam membantu negara-negara peminjam untuk mengatasi masalah ekonomi dan pembangunannya.

\section{Tabel 1}

The Augmented Washington Consensus

\begin{tabular}{|c|c|}
\hline Original Washington Consensus & $\begin{array}{l}\text { "Augmented" Washington Consensus } \\
\text { the previous } 10 \text { items, plus: }\end{array}$ \\
\hline 1. Fiscal discipline & 11. Corporate governance \\
\hline 2. Reorientation of public expenditures & 12. Anti-corruption \\
\hline 3. Tax reform & 13. Flexible labor markets \\
\hline 4. Financial liberalization & 14. WTO agreements \\
\hline 5. Unified and competitive exchange rates & 15. Financial codes and standards \\
\hline 6. Trade liberalization & 16. "Prudent" capital-account opening \\
\hline 7. Openness to DFI & 17. Non-intermediate exchange rate regimes \\
\hline 8. Privatization & 18. Independent central banks/inflation targeting \\
\hline 9. Deregulation & 19. Social safety nets \\
\hline 10. Secure Property Rights & 20. Targeted poverty reduction \\
\hline
\end{tabular}

sumber : DANI RODRIK, Journal of Economic LiteratureVol. XLIV (December 2006), pp. 973$987^{16}$

Bawono Kumoro dalam Investor Daily menjelaskan tentang sepuluh butir Washinton Consensus sebagai berikut ${ }^{17}$ : (1) Disiplin fiskal (fiscal austerity). Negara-negara berkembang

\footnotetext{
${ }^{16}$ dgroups.org/file2.axd/560eb968-07a6-44f4.../dec06_rodrik.pdf.
} 
diminta untuk selalu menjaga anggaran agar tetap berada pada posisi surplus. (2) Anggaran belanja negara-negara berkembang diprioritaskan untuk memperbaiki distribusi pendapatan. Pemerintah disarankan lebih banyak membiayai berbagai proyek dan program untuk menaikkan pendapatan kelompok miskin.(3) Sektor fiskal harus direformasi, kebijakan yang harus dilakukan adalah memperluas sektor pemungutan pajak. (4) Sektor finansial perlu diliberalisasikan. Para nasabah harus tetap mendapat suku bunga rill positif dan menghindar perlakuan suku bunga khusus kepada debitor tertentu. (5) Penentuan kurs mata uang dilakukan dengan mempertimbangkan daya saing dan kredibilitas. (6) Perdagangan perlu diliberalisasi. Pemerintah harus menghapus berbagai hambatan yang bersifat kuantitatif agar arus perdagangan berjalan lancar dan efisien. (7) Investasi asing tidak boleh diperlakukan diskriminatif. Investasi asing harus diperlakukan sama dengan investasi domestik karena keduanya mendorong laju roda perekonomian dan menciptakan lapangan kerja. (8) Privatisasi badan usaha milik negara. Hal ini dimaksudkan untuk menaikkan efisiensi dan membantu pembiayaan defisit anggaran negara; (9) Melakukan deregulasi dengan menghilangkan segala hambatan bagi perusahaan baru yang hendak masuk ke pasar. Iklim kompetisi pasar harus diciptakan. (10) Pemerintah harus menghormati dan melindungi hak cipta, untuk mengembangkan inovasi.

Kebijakan dalam Washington Consensus tersebut merupakan arah dasar dari kegiatan ekonomi pasar dalam perkembangannya saat ini. Hal itu dikarenakan setiap bentuk pembangunan ekonomi negara-negara didunia, terutama negara-negara berkembang dan negaranegara miskin telah terpusat pada kebijakan lembaga-lembaga ekonomi dunia seperti IMF, World Bank, WTO. Ketiga lembaga dunia ini adalah agen dari kebijakan Washington Consensus, karena dasar dari setiap kebijakan pembangunan ekonomi dan resep untuk mengatasi krisis dari ketiga lembaga tersebut disusun berdasarkan Washington Consensus. Terlebih lagi ketiga lemabaga keuangan dunia tersebut didirikan dibawah kepemimpinan PBB dimana kekuatan Amerika Serikat sangat kuat dalam organisasi ini.

\section{Kebijakan Politik Vladimir. V Putin}

Vladimir V. Putin merupakan calon independen pada pemilihan presiden tahun 2000. Kekuatan politik Putin didapat dari para mantan anggota KGB yang di kenal dengan sebutan

\footnotetext{
${ }^{17}$ Bawono Kumoro, Daily Investor, http://www.investor.co.id/home/subsidi-dan-haluan-ekonomi-indonesia/38965, Minggu, 24 Juni 2012 |0:27.
} 
Silvoki. Mantan anggota KGB yang dikenal Vladimir V. Putin secara dekat itu dipilih olehnya sebagai rekan kerja baik dikabinet maupun di parlemen. Keberadaan para sloviki inilah yang dinilai sebagai kekuatan politik yang sulit ditandingi oleh lawan-lawan Putin.

Jiwa nasionalisme yang tertanam pada setiap mantan anggota KGB membawa mereka memjalankan tugasnya dengan visi mensejahterakan bangsa dan rakyatnya. Hal itu terbukti dengan kebijakan dan sikap para siloviki yang tegas mendukung presiden Vladimir.V Putin dalam melakukan tindakan pembersihan korupsi baik dipemerintahan maupun sektor swasta di negara Rusia. "Shoback menyatakan bahwa, orang- orang yang terlatih dengan mentalitas yang berbeda, orang muda dan energik diperlukan. Mereka harus mengambil alih kekuasaan.Mereka adalah orang yang tahu menjalankan tugas-tugasnya."18

Dalam menjalankan tugasnya sebagai presiden Rusia Vladimir V. Putin berusaha melakukan reformasi di segala bidang pemerintahan dan sistem perekonomian.Reformasi itu bertujuan mengatasi krisis yang terjadi saat itu.Dalam artikel 80 dinyatakan bahwa presiden adalah perwakilan federasi Rusia didalam politik domestik dan kebijkan luar negeri, serta menerapkan arahan yang langsung atas kebijakan negara baik domestik maupun asing. ${ }^{19}$ Dalam system pemerintahan perubahan yang di lakukan oleh Presiden Putin diantaranya:

\section{a. Reformasi Lembaga Pemerintah dan Sistem Pemilihan Aparatur Negara}

Reformasi yang dilakukan Vladimir Putin terjadi pada sistem kerja Duma (majelis rendah di Rusia), sebelum pemerintahan Putin Duma digunakan untuk menjalin hubungan Intrapemerintahan dengan menjalin hubungan langsung individu-individu dengan kementrian untuk melobi dukungan. Pada April 2000 praktek itu dilarang pihak kementerian diperintahkan untuk membuat kesepakatan melalui jalur resmi yaitu perwakilan pemerintahan untuk Duma. ${ }^{20}$ Pada parlemen disahkan kebijakan baru yaitu, kenaikan electoral threshold dari 5\% menjadi 7\%, dan meniadakan pemilihan suara against all. Peraturan ini membuat peluang tokoh oposisi seperti PM Kasyanov dan Gary Kasparov untuk berkuasa menjadi sangat kecil. ${ }^{21}$ Kebijakan lain yang cukup drastis terjadi pada peran Duma dan lembaga-lembaga pemerintah yang hanya diberi

\footnotetext{
${ }^{18}$ Saragih, Op. Cit., Hal 100

${ }^{19}$ Emelia Yustiningrum, Jurnal Penelitian Politik, Partai Politik Pemilu dan pemerintahan Rusia, Vol.1, No. 1,2004: 95-100

${ }^{20}$ Thomas F. Remington, "Putin and Duma, Post-Soviet Affair", Vol. 17.No. 4, 2001. PP. 285

21 Susanto Putjo Martono, Kompas, "Siapa penganti Putin”. 28 September, 2007. Http://www2.kompas.com/kompas-cetak/0709/28/ln/3870742,htm.
} 
wewenang untuk megesahkan undang-undang dan kebijakan yang dibuat oleh presiden diantaranya, nasionalisasi, penetapan pajak,peraturan administrasi pemerintahan, investasi baru, dan monopoli sumber daya alam dan migas. Duma tidak lagi berperan dalam pengambilan keputusan kebijakan-kebijakan pemerintah, namun hanya mengesahkan saja kebijakan yang dibuat oleh presiden dan kabinet.

Pada 13 September 2004, Presiden Vladimir V. Putin mengumumkan rencana penghapusan pemilihan umum regional (pemilihan gubernur) di 89 provinsi. $^{22}$ Sistem pemilihan gubernur menjadi hak kremlin. Awalnya daftar nama calon gubernur diajukan kepada Presiden untuk dipilih atau ditolak sebagai nominasi. Dengan demikian ada perubahan hak dari para gubernur yaitu mereka kehilangan kendali terhadap anggaran daerah dan kursi jabatan dimajelis tinggi. Kekuasaan menjadi terpusat dikremlin, ini adalah upaya presiden Vladimir V. Putin untuk mengembalikan pengawasan kekayaan alam pada negara serta membatasi investor asing masuk ke Rusia. Disisi lain sentralisasi yang dilakukan oleh Presiden Vladimir V. putin menunjukan sifat otoriternya serta system kekuasaan negara yang mutlak atau kembali ke sistem sosialis.

Kekuatan Presiden Vlaimir. V Putin terlihat dari parlemen, baik Majelis Tinggi (Dewan Federasi) dan Duma, dikuasai partai-partai pendukung Presiden Putin, terutama partai United Russia yang menguasai 309 dari 450 kursi Duma. Presiden Vladimir V. Putin memenangkan pemilu kedua pada tahun 2004 melalu partai ini. Penguasaan lembaga-lembaga oleh para pendukung Putin dilakukan agar setiap kebijakan yang diputuskan oleh presiden dapat berjalan lancar.

Strategi politik domestik presiden Vladimir V. putin dapat dikategorikan menjadi tiga komponen penting yaitu, mempertahankan prinsip-prinsip demokrasi, memperbaiki sistem multi partai, dan memperkuat masyarakat sipil. $^{23}$ Semua komponen penting inilah yang coba di realisasikan presiden Vladimir.V Putin dalam kebijakan Reformasi lembaga permrintahan pada masa kepemimpinannya.

Kebijakan dan langkah-langkah yang diambil Presiden Vladimir V. putin dalam periode kepemimpinan pertamanya 2000-2004 mendapat dukungan dari rakyat Rusia, hal itu terbukti

22 KOMPAS. "Putin: Rusia akan tetap berada di jalur Demokrasi". 25 September 2004.http://www2.kompas.com/Kompas-cetak/0409/25/utama/1288234.htm.

${ }^{23}$ Emelia Yustiningrum, Op. Cit, hal.106. 
pada pemilu maret 2004 presiden Vladimir. V. Putin kembali memenangkan pemilu presiden dan kembali memimpin Rusia pada periode 2004-2008. Presiden Vladimir V. Putin menang mutlak setelah memperoleh suara sebanyak 49. 565.238 suara atau 71,31\% pada pemilu 2004. Dalam periode kedua kepemimpinannya ini presiden Vladimir V. Putin tetap menjadikan dasar dari semua kebijakannya adalah kepentingan rakyat Rusia dan mengembalikan kejayaan masa lalu negara Rusia.

\section{Tabel 2}

\section{Hasil Pemilu presiden Rusia pada 14 Maret 2004}

\begin{tabular}{|l|r|r|}
\hline Kandidat & Total Suara & Persentase \\
\hline Vladimir Putin & 49.565 .238 & 71,31 \\
\hline Nikolai Kharitonov & 9.513 .313 & 13.69 \\
\hline Sergei Glazev & 2.850 .063 & 4.10 \\
\hline Irina Khakamada & 2.671 .313 & 3.84 \\
\hline Oleg Malyshkin & 1.405 .315 & 2,02 \\
\hline Sergei Mironov & 524.324 & 0,75 \\
\hline Suara kandidat lain & 2.396 .219 & 3.45 \\
\hline
\end{tabular}

Sumber: http://www.rferl.org/specials/russianelection/archives/partywinners.asp, 7 April 2004.

\section{b. Kebijakan Politik Luar Negeri Vladimir. V Putin.}

Selain melakukan perubahan pada perpolitikan didalam negeri presiden Vladimir.V Putin juga melakukan perubahan dalam arah politik luar negerinya. Kebijakan luar negeri Vladimir V. Putin di kenal dengan kebijakan Near Abroad. ${ }^{24}$ Kebijakan ini berarti memposisikan Rusia dalam hubungan dengan negara-negara bekas jajahan Soviet. Negaranegara Unieropa juga mendapat perhatian khusus bagi Vladimir V. Putin hubungan kerjasama dijalin kembali, setelah terputus sebelumnya. Hubungan kerjasama dengan Inggris juga buka kembali setelah 129 tahun terhenti. Hal yang juga mendapat sorotan Internasional adalah sikap Vladimir V. Putin yang menolak Invansi Amerika Serikat ke Irak. Selain memperlihatkan posisinya Rusia dalam dunia Internasional peristiwa ini juga mempererat hubungan Rusia dengan Irak, berlawanan dengan Presiden Boris Yeltsin yang menyatakan anti-Irak, Presiden Vladimir Putin mempertahankan hubungan baiknya dengan negara Irak dalam politik Luar negerinya.

\footnotetext{
${ }^{24}$ Near Abroad mengacu pada negara-negara bekas jajahan Unisoviet baik yang terhimpun dalam CIS maupun tidak.
} 
Bukan hanya di wilayah Eropa dan sekitarnya, presiden Vladimir V. Putin melakukan kerjasama juga dengan Kawasan Asia dan Afrika yang mendapat tempat bagi kebijakan luar negeri Vladimir V. Putin. Hal itu terlihat dalam kerjasama ekonomi dalam organisasi dunia BRICs ada China dan South Africa yang menjadi mitra kerjanya. Vladimir V. Putin juga berkunjung ke Indonesia pada era Presiden Megawati Soekarno Putri. Selanjutnya pada masa pemerintahan presiden presiden Susilo Bambang Yudoyono Rusia dan Indonesia menandatangani dua nota kesepakatan atau MoU antara pertamina dengan LukOil, sekitar 1 miliyar dollar AS dan MoU antara PT. Aneka Tambang dengan Rusia dalam pertambangan Bauksit dan almunium sekitar 3 miliyar dollar AS. Rusia juga memberikan kredit lunak bagi Indonesia jika ingin melakukan pembelian peralatan militer ${ }^{25}$

Proses perumusan kebijakan luar negeri di Rusia melibatkan: Presiden, Majelis Federal (duma dan dewan federal), Security Council, kementerian luar negeri. Dalam Konstitusi negera Federasi Rusia tahun 1993 memberi kekuatan dan peran yang besar terhadap eksekutif terutama presiden. Oleh karena itu Presiden Vladimir V. Putin merupakan tokoh sentral dalam kebijakan politik luar negeri Rusia pada tahun 2000-2008. Tujuan dari politik luar negeri Rusia pada masa itu ialah kombinasi berimbang dari kepentingan individu, masyarakat dan negara dalam ruang ekonomi, politik domestik, sosial, internasional informasi, militer, perbatasan, ekologi dan lain-lain. Oleh karenanya kebijakn politik luar negeri Rusia akan selalu berdasarkan pada setiap aspek kepentingan nasional yang telah dirumuskan.

Presiden Vladimir V. Putin juga berusaha memperkenalkan nilai-nilai patriotisme dan tradisi dalam visinya. Ia juga menyatakan pemberontakan Chechnya sebagai pemberontakan separatis yang dapat membahayakan kedaulatan negara federasi Rusia. Pemberontakan itu disebut oleh Vladimir V. Putin sebagai gerakan terorisme. Hal ini juga membawa hubungan Rusia dan Amerika Serikat menjadi lebih baik karena Rusia berusaha menunjukan simpatinya terhadap Amerika Serikat yang menyatakan perang terhadap terorisme. Disisi lain Presiden V. Putin menyadari sikap NATO dan Amerika Serikat yang ingin menyingkirkan Rusia dari kelompak kekuatan dunia, namun Vladimir Putin menunjukan sikap pragmatisnya dengan menghindari perang secara terbuka dengan Amerika Serikat dan sekutunya. Presiden Vladimir

${ }^{25}$ www.antara.com, diakses 10 April 2012. 
mengungkapkan kebijakan politik luar negerinya dalam pidato dihadapan dewan parlemen sebagai berikut ${ }^{26}$ : "The Foundation of This is policy is pregmatism, economic effectiveness, and priority of national taks" ( dasar dari kebijakan adalah pragmatis, efektivitas ekonomi, dan prioritas terhadap tujuan negara) dikesempatan lain Presiden Vladimir V. Putin juga meminta seluruh rakyat Rusia untuk tidak melupakan kejayaan masa lalu. Semua hal yang disampaikan oleh presiden Vladimir V. Putin bertujuan untuk menjadikan Rusia sebagai "Kekuatan Baru Dunia” dalam sistem dunia multipolar. Untuk mencapai tujuan itu presiden Vladimir V. Putin memulainya dari Reformasi internal terutama ekonomi, Rule of law, dan sistem birokrasi. ${ }^{27}$ Dengan ini Presiden Vladimir.V Putin menyatakan bahwa dasar dari kekuatan luar negeri Rusia adalah kekuatan politik ekonomi internal Rusia oleh karenanya presiden Vladimir V. Putin berusaha membagun ekonomi politik nasional untuk dapat bersaing dan menjadi kekuatan baru Dunia. Dalam bidang keamanan negara Rusia berusaha menjalin kerjasama dengan negara-negara di sekelilingnya. Saat ini Rusia di buat khawatir oleh kehadiran pangkalan militer NATO yang mengarah ke negara Rusia. Putin berusaha melakukan sebuah kerjasama keamanan dengan negara yang ada di timur dan selatan. Organisasi Perjanjian Keamanan Kolektif untuk keamanan regional atau Collective Security Treaty Organization (CSTO) yang dipimpin Rusia dengan tujuan mengimbagi kekuatan NATO, anggota organisasi ini antara lain: Armenia, Belarusia, Kazakhstan, Kyrgyzstan, Tajikistan, dan Uzbekistan. Organisasi keamanan lain yang di bentuk Rusia bersama Cina adalah Shanghai Corporation Organization (SCO). Organisasi ini dibentuk atas pandangan yang sama antara Rusia dan Cina terhadap AS (yang dominan dalam NATO) yang di anggap mulai ikut campur wilayah Asia Tengah, yaitu negara-negara bekas pecahan unisoviet yang juga tergabung dalam SCO diantaranya: Kazakhstan, Tajikistan, Kirgyzstan dan Uzbekistan. Kerjasama keamanan yang dilakukan oleh Rusia bukan hanya bertujuan untuk mengimbangi kekuatan militer NATO namun juga sebagai pembentukan kelompok negara penyangga bagi keamanan dan stabilitas negara Rusia. Presiden Vladimir V. Putin berusaha merangkul setiap kepala pemerintahan yang bekerjasama dengan Rusia. Kekuasaan presiden dalam anggakatan bersenjata diatur dalam artikel 87 dan 88 bahwa presiden merupakan panglima anggkatan

\footnotetext{
${ }^{26}$ R.de Archellie, Glasnost, Pragmatisme Polotik luar Negeri Vladimir V. Putin, Vol 4. No.2, Oktober 2008-Maret 2009, Hal.53

${ }^{27}$ Ibid
} 
bersenjata negara. Presiden memiliki kekuasaan untuk mendeklarasikan kondisi negara dalam keadaan perang atau dalam keadaan darurat. ${ }^{28}$ Kebijakan ini yang menjadi dasar dalam setiap pengambilan keputusan Putin dalam bidang pertahanan dan keamanan Rusia, begitu juga dalam penetapan anggaran pertahanan dan keamananya. Semenjak pengunduran diri Yeltsin pada desember 1999 presiden Vladimir.V Putin telah merumuskan kebijakan pertahanannya.

Tabel 3

Perbandingan pembiayaan militer Rusia-NATO (2000-2009, dalam miliar dolar

\begin{tabular}{|c|c|c|c|}
\hline & $\begin{array}{c}\text { Pembiayaan } \\
\text { militer }\end{array}$ & $\begin{array}{c}\text { Pengadaan AS Pèngkapan } \\
\text { militer }\end{array}$ & $\begin{array}{c}\text { Pembiayaan penemuan dan } \\
\text { pengembangan militer }\end{array}$ \\
\hline Rusia & 44 & 9 & 3 \\
\hline NATO & 850 & 200 & 70 \\
\hline
\end{tabular}

Sumber: data pembaiayaan militer SIPRI (Stockholm International Peace Research Institutet) (2010)

Dari tabel diatas dapat disimpulkan bahwa kekutan militer Rusia masih jauh di bawah kekuatan militer NATO, oleh karenanya Presiden Vladimir V. Putin berusaha menghimpun kekuatan sebagai sekutunya. Semenjak Vladimir V. Putin menjabat sebagai Presiden pada desember 1999 ia telah mengeluarkan dua belas dekrit presiden. Setengah diantaranya berkaitan dengan kebijakan militer. Hal ini membuktikan bahwa Presiden Vladimir V. Putin memandang begitu pentingnya sistem pertahanan negara dalam memperjuangkan kepentingan nasionalnya.

Kekuatan negara dalam bentuk militer dan persenjataannya merupakan alat dalam menunjukan posisi suatu negara dimata dunia. Kekuatan negara dalam bentuk ini juga dapat menjadi alat untuk menggetarkan negara-negara lawan. Oleh karenanya pengembangan kekuatan militer dan persenjataan kembali mendapat fokus utama pada pemerintahan presiden Vladimir V. Putin, setelah pada masa Reformasi Gorbachev dan masa pemerintahan Boris Yeltsin masalah militer kurang mendapat perhatian. Kebangkitan persenjataan dan militer Rusia tidak dapat terjadi jika perekonomian Rusia belum stabil. Karena perekonomian Rusia telah mengalami kebangkitan maka anggaran militer Rusia dapat bertambah.

\footnotetext{
${ }^{28}$ Emelia Yustiningrum, Op. Cit, hal. 104.
} 


\section{c. Pengaruh Positif dan Negatif bantuan IMF pada bidang Politik di Rusia.}

Pengaruh Positif terlihat pada proses politik Cheks and balances dan di bentuknya dewan perwakilan rakyat atau Duma yang memberikan kebebasan pada seluruh Rakyat untuk menyampakain inspirasi dan mengawasi jalannya perpolitikan. ${ }^{29}$ Pengaruh Negatif terlihat pada Demokrasi yang memberikan kebebasan pada tiga kelompok politik untuk memperjuangkan kepentingannya di antaranya; Kelompok radikal Reformis yang menghendaki pasar bebas, Kelompok konservatif-nasionalis yang merupakan kelompok oposisi pemerintahan pemerintahan presiden Yeltsin, kelompok tengah yang kelompok yang tergantung konteks situasi dan politik di Rusia. ${ }^{106}$ Proses perjuangan kepentingan kelompok tersebut yang terkadang berjalan anarkis dan membuat perpolitikan di Rusia menjadi tidak kondusif.

\section{Kebijakan Ekonomi Vladimir V. Putin}

Seperti telah dibahas sebelumnya bahwa sistem ekonomi dunia terpolarisasi dalam dua kutub yaitu ekonomi nasional dan ekonomi pasar. Presiden Vladimir V. Putin Menyatakan, “ Kita bisa meraih masa depan jika kita mengelola negara dengan kombinasi antara prinsip ekonomi pasar dan demokrasi yang sesuai dengan realitas di Rusia. ${ }^{, 30}$ Pada kenyataannya dalam setiap kebijakan ekonomi yang dijalankan Oleh Presiden Vladimir.V Putin sangat kentara peran negara yang kuat. Hal itu dikarenakan Rusia masih menganut sistem paternalistik yang sangat kuat.

Sistem paternalistik merujuk pada peran negara yang lebih dominan dibandingkan dengan peran sipil. Ahli Sosial asal Belanda, Geertz Hofstede pernah melakukan penelitian di Rusia dan menyimpulkan bahwa Rusia memiliki indeks Power distance (jarak kekuasaan) yang relative tinggi. Rakyat di negara dengan indeks Power distance yang tinggi cenderung menerima otoritas yang kurang demokratis. ${ }^{31}$

Dikesempatan lain Presiden Vladimir Putin menyatakan "Kami telah melakukan banyak hal yang membenaskan Rusia dari kehancuran domestik. Kami mengembalikan Rusia ke jalur pembagunan evolusioner. Saya masih ingin melanjutkan itu, dimana kami

\footnotetext{
${ }^{29}$ Monica Dian Adelina, Skripsi Sentralisasi Demokratik Vladimir Putin dalam Mengatasi Krisis

${ }^{30}$ Alkatiri, Op. Cit,. hal. 108.

${ }^{31}$ Simon Saragih, Op. Cit., hal. 107.
} 
tidak menginginkan pihak asing campur tangan didalam proses situ." ${ }^{, 32}$ Hal ini menegaskan sikap Presiden yang menolak negara lain maupun lembaga-lembaga keuangan dunia mengatur jalannya pembagunan dan perkembangan ekonomi di Negara Rusia. Pernyataan ini juga menegaskan bahwa segala bentuk kebijakan yang diajukan IMF terhadap negara Rusia dan telah dijalankan oleh pemerintahan sebelumnya akan dikaji ulang dan direvisi oleh pemerintah Rusia. Pemerintah Rusia akan menjalankan kebijakan yang disepakati oleh presiden, kabinet, dan parlemen untuk mencapai kesejahteraan masyarakat Rusia. Kehadiran pihak Asing akan tetap dipertahankan dilindungi dengan catatan usaha yang mereka kerjakan memberi keuntungan bagi negara Rusia.

\section{a. Pengembalian Aset negara oleh pengusaha swasta.}

Tujuan utama dari kebijakan ekonomi dalam negeri Vladimir V. Putin adalah melakukan stabilitasi dan keamanan sektor ekonomi, ia melakukan pengembalian aset negera dari tangan swasta kepada pemerintah. Hal ini merupakan kebijakan berlawanan dari saran IMF yang menganjurkan agar Rusia melakukan Privatisasi, yang memberi jawaban atas penolakan Presiden Vladimir V. Putin terhadap campur tangan pihak asing di Rusia. Untuk mencapai tujuan ekonominya Vladimir V. Putin dan kabinetnya berusaha untuk memaksimalkan sumber pendapatan negara baik melalui pengelolahan maksimal sumber daya alam maupun penarikan pajak. Di tahun 2003 ia mengumpulkan kembali aset-aset negara disektor migas. Kontrol terhadap usaha strategi minyak, gas dan mineral dilakukan. ${ }^{33}$ Kebijakan ini menjadi langkah awal karena pemasukan devisa negara Rusia terbesar didapat dari sektor migas. Saat bersamaan harga minyak dunia mengalami kenaikan yang cukup tinggi. Hal itu secara cepat menambah pundi-pundi devisa negara Rusia. Dalam menjalankan kebijakannya Vladimir V. Putin sangat tegas dan tidak pandang bulu, pengusaha yang tidak menuruti peraturan pemerintah dilaporkan ke pengadilan. Beberapa pengusaha yang diajukan ke pengadilan oleh Vladimir V. Putin diantaranya : Vladimir Nekasov, CEO Arbat Prestige (perusahaan real estate), Mikhail Khodorkovsky pemilik perusahaan Yukos (perusahaan minyak terbesar di Rusia). Pada masa pemerintahan presiden Vladimir Putin tepatnya Oktober 2003 Khodorkovsky

\footnotetext{
${ }^{32}$ Ibid., hal. 108

${ }^{33}$ Ibid., hal 109.
} 
dengan dugaan sejumlah pekerja dari perusahaannya telah melakukan korupsi, penyuapan dan pembunuhan. ${ }^{34}$ Tuduhan lain yang di tujukan kepada Khodorkovsky adalah pencurian aset negara karena ada penipuan yang Ia lakukan untuk memindahkan aset swasta Rusia ke swasta asing, tindakan pengelapan pajak yang merugikan negara, dan kesalahan yang membuatnya harus di tahan pada masa pemerintahan Presiden Vladimir V. Putin adalah tindakannya melawan Presiden Vladimir V. Putin. Khodorkovsky membiayai partai-partai oposisi, oligarki, dan menyuap 100 anggota parlemen di majelis rendah Rusia (Duma) untuk mempengaruhi pemerintah membuat kebijakan yang menguntungkan bisnisnya. ${ }^{35}$

Kebijakan yang juga menguntungkan negara adalah melakukan pengetatan aturan konservasi lingkungan. Pemerintah membuat peraturan konservasi lingkungan yang ketat dan juga target waktu bagi kontraktor yang sulit untuk dipenuhi, hal ini bertujuan untuk menekan kontraktor menjual proyeknya ke perusahaan milik negara. Beberapa proyek yang dijual sebagai hasil dari kebijakan ini adalah : Shaklain-2 (Shell-Mitsui/Mitsubishi), proyek penjualan gas (Exxonmobil), Kovikta gas field dan east Siberia field (TNK-BP). ${ }^{36}$

Pengembalian aset negara disektor migas bertepatan dengan naiknya harga minyak dunia saat itu. Hal ini membuat cadangan devisa Rusia kembali terisi. Reformasi ekonomi yang dilakukan Presiden Putin berhasil. Rusia menghasilkan minyak 9,5 juta barrel per hari yang bisa ditingkatkan menjadi lebih dari 10 juta barrel perhari. Volume ekspor minyak per hari sekitar 7 juta barrel (2006) sehingga dengan harga minyak dunia yang di atas 75 dollar AS per barrel seperti saat itu, pendapatan negara dari sektor migas cukup besar nilainya. Kontribusi terbasar devisa Rusia didapat dari ekspor gas alam mencapai 674 miliar dollar AS pada tahun 2006.

Sektor lain yang juga menjadi penopang dari pertumbuhan ekonomi Rusia adalah produksi alat-alat persenjataan perang (ALUSISTA). Banyak pesanan senjata kepada Asosiasi Industri Militer/Penerbangan Rusia atau AVPK SUKHOI dari negara-negara di Asia (terutama Cina dan India). Asosiasi Industri Militer dengan cepat memperoleh dana US\$ 4 miliar dari penjualan senjata ke India dan China. Dalam perkembanga ekonomi

\footnotetext{
${ }^{34}$ Greenspan, Op. Cit,. hal.331

${ }^{35}$ Saragih $O p$. Cit., hal.78.

${ }^{36}$ Ibid..hal. 75
} 
yang terus meningkat dan cadangan devisa yang besar nilainya pemerintah Rusia tidak melupakan peran IMF dan pinjaman dana yang diberikan. Rusia segera membayar lunas utang-utangnya di IMF dan Paris Club. Bukan hanya dapat membayar hutang saat ini Rusia menjadi negara dengan urutan ketiga dunia yang memiliki cadangan devisa terbesar.

\section{b. Kebijakan di Sektor Pajak}

Pada pemerintahan Presiden Boris Yeltsin sektor pajak tidak berjalan secara bersih, karena banyak pengusaha yang melakukan pengelapan pajak. Pembayaran pajak pada masa itu menjadi lahan untuk para koruptor. Banyak pengusaha yang memilih melakukan suap terhadap birokrat terkait dari pada membayar pajak kepada negara.

Reformasi sektor pajak di era kepemimpinan Vladimir.V Putin bertujuan untuk mencegah penghindaran pembayar pajak oleh Wjib pajak. Pembayaran pajak digunakan sebagai monitor pendapatan dan pengeluaran untuk sektor sumber daya alam. Pada tahun 2000 diberlakukan Undang-Undang fiskal yang baru. Peraturan itu memberi jaminan terhadap investor dalam maupun luar negeri dalam penanaman modalnya, juga membantu penarikan modal masuk ke Rusia. Pemerintah juga bekerjasama dengan IMF dalam menetapkan pajak. Kebijakan itu berupa penetapan pajak yang lebih tinggi disektor energi dan lebih rendah pada sektor perindustrian, komersial dan sektor pelayanan. Tingginya pajak pada sektor energy membuat Rusia dapat melakukan subsidi silang dalam pembagunan ekonominya.

\section{c. Pengaruh Positif dan Negatif IMF terhadap bidang Ekonomi Rusia}

Pengaruh Positif, IMF memberikan bantuan dana tunai, merancang program-program perbaikan perekonomian Rusia dan mengirimkan staff-staff pengawas jalannya perbaikan ekonomi di Rusia, membuka pasar Rusia bagi Investor Asing.

Pengaruh Negatif, beberapa program IMF seperti Shock Teraphy dan Privatisasi terkesan dipaksakan untuk dilaksanakan di Rusia hal itu membuat perekonomian Rusia yang sebelumnya terpusat ke pemerintah mengalami masa transisi yang sulit untuk berkembang serta mengakibatkan krisis yang berkepanjangan. 


\section{E. Keberhasilan Pemerintahan Vladimir V. Putin}

Selain investasi dalam negeri Rusia yang mengalami peningkatan, inevstasi luar negerinya juga mengalami lonjakan yang cukup hebat. Investasi Rusia tersebar dinegaranegara CIS dan Eropa di kawasan ini Rusia menanamkan modalnya dalam sektor: pertambangan migas, jalur pipa migas, peralatan militer dan properti. Selain dua kawasan tadi Rusia juga melakukan penanaman modal di sebagian besar negara ASEAN diantaranya : Indonesia, Singapura, Thailand, Kamboja, Vietnam, Laos, Malaysia. Bidang yang minati Rusia pada kawasan ASEAN adalah migas, barang tambang, tegnologi pesawat, perikanan dan pariwisata.

\section{Grafik 1}

pertumbuhan Ekonomi Rusia
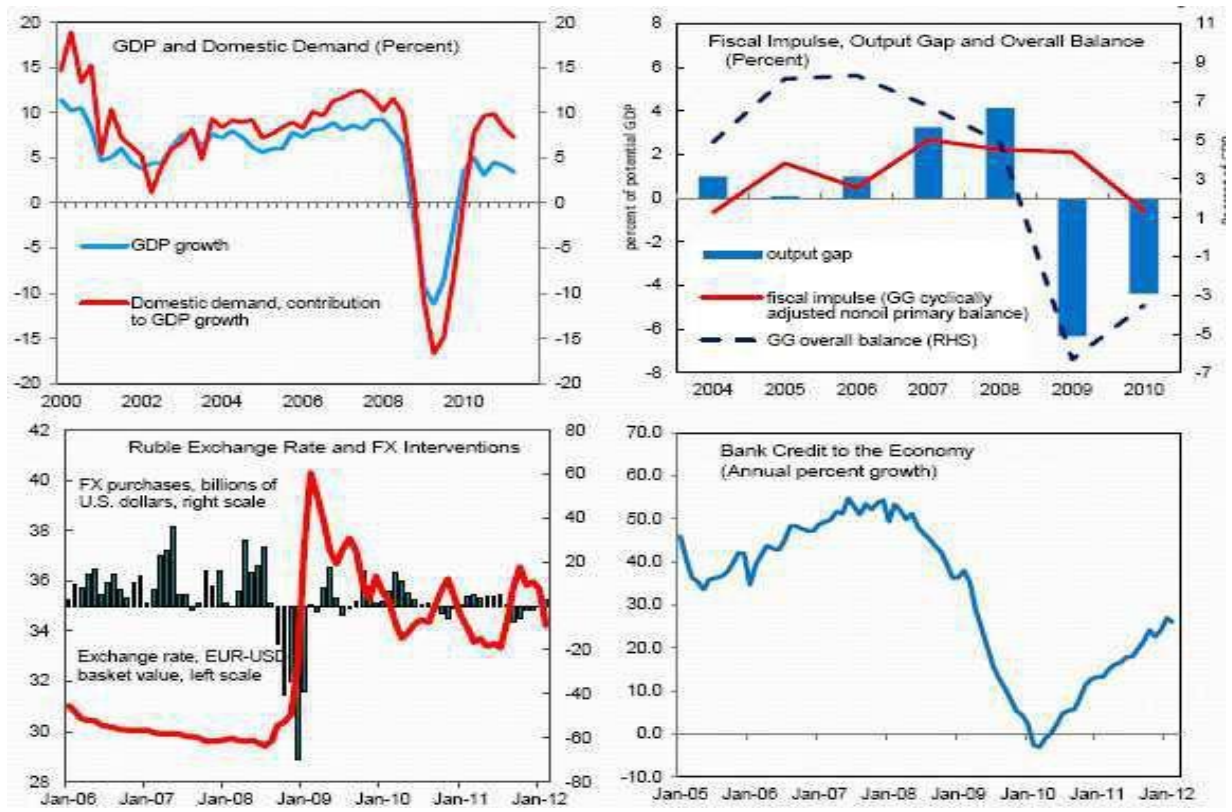

Sumber :Russian Federation Economic Outlook and Policy Challenges Odd Per Brekk Senior Resident Representative Spring 2001

Keberhasilan lain dari kebijakan ekonomi Vladimir Putin adalah berkurangnya penganguran dan warga miskin di Rusia. Hal ini dapat di lihat dalam grafik peningkatan GDP Rusia yang selalu mengalami peningkatan pada masa kepemimpinan Putin dari tahun 2000-2008. Grafik diatas mencerminkan pertumbuhan ekonomi Rusia yang sangat cepat 
mengalami peningkatan. Sesuatu yang sangat menabjukan dalam perkembangan ekonomi suatu bangsa. Karena pertumbuhan itu terjadi dalam waktu singkat. Kepemimpinan Vladimir V. Putin yang semula dinilai dunia barat tidak berbeda jauh dengan presiden Boris Yeltsin ternyata salah, Presiden Vladimir Putin merupakan pemimpin yang tegas dan pintar dalam melihat situasi politik.

\section{Grafik 2}

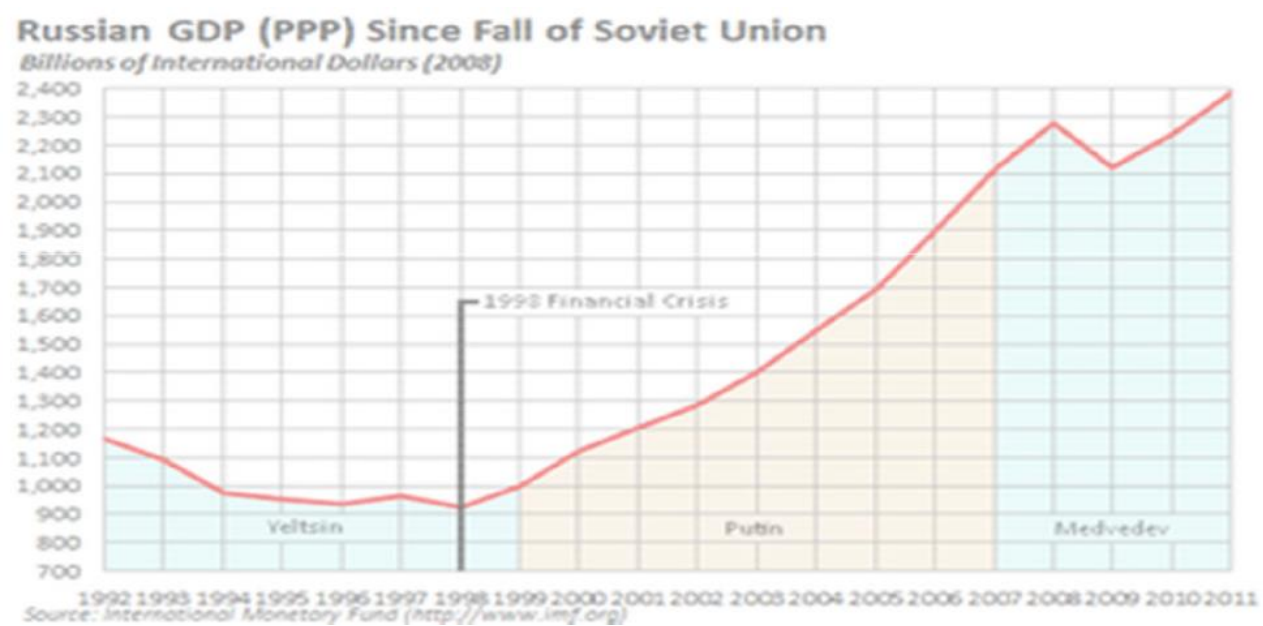

Grafik GDP Rusia tidak pernah mengalami penurunan dalam masa pemerintahan Vladimir V.Putin. Dengan pendapatan negara yang selalu surplus setiap tahunnya cadangan devisa negara Rusia juga menjadi besar selama mas pemerintahan Vladimir. V Putin. Cadangan devisa negara Rusia mencapai 80 miliyar dollar AS. ${ }^{37}$ Keberhasilan Kebijakan ekonomi Rusia dibawah kepemimpinan Vladimir Putin membawa dampak pada:

\section{a. Peningkatan Nilai Eksport}

Meningkatnya produksi dalam negeri Rusia disetiap sektor industry membuat negara Rusia harus melakukan eksport terhadap barang-barang hasil produksinya. Tujuan eksport negara Rusia adalah negara-negara bekas jajahan soviet, negara Unieropa dan Amerika dan negara di Timur Tengah. Eksport Rusia bukan hanya persenjataan perang dan migas saja sektor pertaniaan yang juga mendapat perhatian dari Vladimir V. Putin menjadi komoditas lain dari eksport Rusia

${ }^{37}$ Muhammad Fakhrur Razi, “ Nasionalisasi Asset Migas: Tinjauan Sejarah” 
Tabel 4.

Perkembangan ekonomi federasi Rusia dalam sektor Perdagangan pada tahun

\begin{tabular}{|l|c|c|c|c|c|c|c|c|c|c|c|c|}
\hline & 1992 & 1993 & 1994 & 1995 & 1996 & 1997 & 1998 & 1999 & 2000 & 2001 & 2002 & 2003 \\
\hline $\begin{array}{l}\text { Russian* } \\
\begin{array}{l}\text { Export } \\
\text { (F.O.B) }\end{array}\end{array}$ & 42,4 & 44,3 & 49,2 & 63,7 & 69,2 & 68,4 & 57,6 & 62,2 & 89,3 & 85,4 & 91,0 & 113,0 \\
\hline $\begin{array}{l}\text { Russian* } \\
\text { Import } \\
\text { (C.I.F) }\end{array}$ & 37,0 & 26,8 & 28,3 & 33,2 & 31,5 & 38,8 & 32,3 & 21,9 & 22,3 & 30,7 & 36,0 & 44,1 \\
\hline $\begin{array}{l}\text { Trade* } \\
\text { Turnover }\end{array}$ & 79,4 & 71,1 & 77,5 & 96,9 & 100,7 & 107,2 & 89,9 & 84,1 & 111,6 & 116,1 & 127,0 & 157,1 \\
\hline Balance & $+5,4$ & $+17,5$ & $+20,9$ & $+30,5$ & $+37,7$ & $+29,6$ & $+25,3$ & $+40,3$ & $+67,0$ & $+54,7$ & $+55,0$ & $+68,9$ \\
\hline
\end{tabular}

* In Billion US Dollar (\$)

Source : Official Russian State Custom Committee Statistics, 1994-2004: "Foreign trade: Change of Time"

Tabel di atas membuktikan bahwa pemerintahan Putin tetap menjalankan ekonomi pasar sebagai kelanjutan dari kebijakan ekonomi nasionalisnya. Rusia bersedia membuka diri bagi modal asing yang membawa nilai positif bagi perkembangan ekonomi nasional. Keberhasilan Putin dalam mengolah energi Rusia dan menjadikannya sebagai instrumen diplomasi dalam meningkatkan posisi tawar Rusia di dunia internasional. Posisi Uni Eropa yang lemah terhadap keunggulan komparatif Rusia, membuat Rusia menjadi pemasok seperempat kebutuhan energi di Eropa. Hal itu membuat negara-negara di Uni Eropa memiliki sikap ketergantungan terhadap Rusia terutama dalam masalah suplay migas, karena migas merupakan bahan bakar utama produksi dikawasan itu. Moderenisasi industry energi di Rusia merupakan kebijakan untuk meningkatkan hasil produksi migas dalam menjaga suplai migas kenegara Uni Eropa tetap Stabil.

Sistem perekonomian yang dijalankan oleh Presiden Vladimir V. Putin memiliki kesamaan dengan sistem ekonomi Unisoviet pada masa Stalin. Produksi alat berat, persenjataan, militer, dan migas mendapat perhatian ekstra dalam pemerintahan keduanya. Namun ada perbedaan pada sektor pertanian perkebunan dan peternakan, sepertinya belajar dari pengalaman presiden Stalin presiden Vladimir V. Putin berusaha membangkitkan sektor pertanian, perkebunan dan peternakan. Walau ketiga sektor ini bukanlah penyumbang terbasar devisa negara, namun sektor ini juga memiliki peran penting dalam menstabilkan 
perekonomian dalam negeri. Sehingga saat sector industri alat berat dan persenjataan terkena dampak krisis global maka sector agrarian dapat memberikan kontribusi dalam menstabilkan perekonomian negara.

Tabel 5

Nama-nama Jenis Barang Eksport dan Import Negara Rusia

\begin{tabular}{|c|c|c|c|}
\hline \multirow[b]{2}{*}{ No. } & \multirow[b]{2}{*}{ Jenis- jenis Barang } & \multicolumn{2}{|c|}{2003} \\
\hline & & $\begin{array}{l}\text { Export } \\
(\%)\end{array}$ & Import \\
\hline 1 & Produk makanan dan bahan mentah hasil pertanian & 1.5 & 21.4 \\
\hline 2 & $\begin{array}{l}\text { Barang-barang tambang (gas, minyak, bensin, bijih } \\
\text { besi, batu bara, dll) }\end{array}$ & 60.0 & 1.2 \\
\hline 3 & Produk-produk kimia dan karet & 6.2 & 18.4 \\
\hline 4 & Bahan kulit mentah & 0.2 & 0.4 \\
\hline 5 & Kаул, serbuk kayu, bahan-bahan kertas & 4.3 & 4.5 \\
\hline 6 & Textiles dan footwear & 0.5 & 4.1 \\
\hline 7 & Batu-batu mulia dan batu-batuan murni & 4.6 & 0.1 \\
\hline 8 & $\begin{array}{l}\text { Produk-produk bahan mentah yang mengandung } \\
\text { besi dan tidak mengandung besi }\end{array}$ & 14.3 & 4.9 \\
\hline 9 & Mesin-mesin, peralatan dan peralatan pengangkutan & 7.1 & 40.8 \\
\hline 10 & Lain-lain & 1.3 & 4.2 \\
\hline & Total & $100 \%$ & $100 \%$ \\
\hline
\end{tabular}

Sampai dengan tahun 2003 Rusia telah menempati posisi kesepuluh dalam daftar negara dengan kuaota terbesar di IMF total kuotanya mencapai 2,8\%. Hal itu membuktikan bahwa kekuatan ekonomi Rusia tidak dapat dipandang sebelah mata lagi oleh dunia. Bukan hanya mampu mengatasi krisis ekonomi dinegaranya kepemimpinan presiden Vladimir.V. putin di Rusia juga mampu mengembalikan kejayaan Rusia dalam kekuatan dunia baru dalam sistem multipolar.

\section{b. Pelunasan Hutang Luar Negeri}

Besarnya cadangan devisa yang dimiliki oleh Rusia membuat negara itu dapat melunasi hutang luar negerinya. Pelunasan hutang ini dilakuan secara bertahap oleh Rusia ditahun 2005-2006 dibagi dalam tahap, Febuari 2005 rusia membayar 4,3 miliyar dollar AS kepada IMF untuk melunasi hutangnya. Mei 200515 miliyar dollar AS dikeluarkan dari kas negara untuk membayar hutang kepada kreditor.

"On January 31, 2005, the Russian Federation completed the early repayment of its entire outstanding obligations to the International Monetary Fund (IMF) amounting to SDR 2.19 billion (about US\$3.33 billion). The outstanding obligations of Russia had all 
been contracted under the Extended Arrangement that was approved by the Executive Board on March 26, 1996 (see Press Release No. 96/13)"38

"Pada tanggal 31 Januari 2005, Federasi Rusia menyelesaikan pelunasan awal seluruh kewajiban yang terhutang kepada Dana Moneter Internasional (IMF) sebesar SDR 2,19 miliar (sekitar US \$ 3,33 miliar). Kewajiban yang belum dipenuhi dari Rusia semua telah dikontrak di bawah Arrangement diperpanjang yang telah disetujui oleh Dewan Eksekutif pada tanggal 26 Maret."

Pada Juni 2006 pembayaran hutang pada Paris Club dilakukan dana yang dikeluarkan Rusia sekitar 7,7 Miliyar dollar AS.

\section{F. Pengaruh IMF dan keberhasilan Pemerintahan Vladimir V. Putin}

Pada masa pemerintahan presiden Vladimir V. Putin tidak banyak dana bantuan luar negeri baik dari IMF maupun negara-negara lain yang diberikan ke Rusia. Namun programprogram IMF yang telah dirumuskan dalam agenda perbaikan ekonomi Rusia tetap dijalankan oleh pemerintahan Vladimir V. Putin. Agenda perbaikan itu dijalankan dengan menyesuaikan program IMF dan kondisi ekonomi Rusia. Oleh karenanya IMF mempunyai pengaruh sebagai pembuat arah dasar pembagunan ekonomi Rusia yang liberal dipadukan dengan konsep ekonomi komando yang sesuai dengan kondisi ekonomi politik di negara Rusia.

\section{Kesimpulan}

Kebangkitan ekonomi Rusia tidak dapat dipisahkan dengan bantuan IMF baik dalam bentuk dana tunai, program-program IMF dan staff-staff pengawas, hal ini dikarenakan bantuan IMF yang dianggap membawa Rusia dalam jurang krisis, menjadi alasan kaum nasionalis Rusia menyerukan Reformasi. Kaum Nasionalis yang merupakan eks anggota KGB dan di sebut siloviki menyadari bahwa pihak asing dan IMF tidak bersungguh-sungguh dalam mengatasi krisis di Rusia. Dalam beberapa pidatonya presiden Vladimir V. Putin juga mengobarkan jiwa nasionalis bangsa Rusia untuk menolak pinjaman luar negeri karena telah mengakibatkan krisis yang sangat parah di Rusia. Namun Presiden Vladimir V. Putin tetap menjalankan setiap program IMF yang sesuai dengan kepentingan negara Rusia. Oleh karena itu program-program

\footnotetext{
${ }^{38}$ http://www.imf.org/external/np/sec/pr/2005/pr0519.htm, Press Release No. 05/19 February 2, 2005
} 
IMF masih dijalankan pada masa pemerintahan presiden Vladimir V. Putin namun pelaksanaanya di sesuaikan dengan kondisi negara Rusia.

Pengaruh Negatif bantuan IMF terhadap kebangkitan Ekonomi Rusia adalah : Proses Demokrasi, liberalisasi dan privatisasi pada awalnya berjalan tidak sesuai dengan sistem ekonomi dan budaya Rusia sehingga menimbulkan konflik-konflik sosial. Kesalahan dalam menjalankan program Privatisasi melahirkan kaum oligarki yang serakah sehingga terjadi praktik korupsi yang merugikan negara. Keadaan negara Rusia dalam masa transisi dimanfaatkan pihak asing untuk menguasai asset negara Rusia. Sehingga BUMN banyak dikuasai oleh swasta. Transisi politik dan ekonomi Rusia juga diwarnai oleh sikap Birokrat yang memihak kepada pengusaha, sehingga kasus pengelapan pajak sering terjadi. Pengaruh Positif bantuan IMF terhadap kebangkitan Ekonomi Rusia adalah : Terbukanya Rusia menjadi pasar baru Eropa dan Amerika, membuat Rusia memiliki dana cair untuk pembagunan ekonominya. Terbentuknya sistem perbankan yang efektif dan transparan, setelah kasus Fimaco sistem perbankan mendapat perhatian khusus. Sektor pertanian mulai mendapat perhatian pemerintah di samping sektor industry alat berat dan migas. Terbentuknya sistem perdagangan luar negri yang terorganisir. Perekonomian Rusia mengalami pertumbuhan yang sangat pesat.

\section{DAFTAR PUSTAKA}

Alkatiri,Zeffry 2007. Transisi Demokrasi di Negara Federasi Rusia. Depok: Fakultas Ilmu Pengetahuan Budaya UI.

Arikunto, Suhardimi. 1998. "Rumusan Hipotesa”,Prosedur Penelitian, Jakarta: Pt Rineka Cipta

Barnet,Richard J dan Ronald E. Muller. 1984 Menjangkau Dunia, Jakarta:LP3ES

Clift, Jeremi.2003. Apakah Dana Moneter Internasional Itu?. Washinton D.C : International Moneter Fund.

Couloumbis,Theodore A. 1984.Pengantar Hubungan Internasional Keadilan dan Power,Jakarta,Putrabardin

Deliarnov. 2006. Ekonomi Politik. Jakarta: Erlangga.

Galeotti,Mark. 1997. Gorbachev And His Revolution, United States of America:ST. Martin's Press,INC Greenspan, Alan,2007.Abad Prahara, Jakarta: Gramedia Pustaka Utamal Isaak,Robert A,1995. Ekonomi Politik Internasional, Yogyakarta: PT. Tiara Wacana Yogya Jackson, Robert dan Georg Sorensen, 2005. Pengantar Studi Hubungan Internasonal, jakarta: Pustaka Belajar

Kadi, Saurip.2 008. Megutamakan Rakyat- Wawanara Mayor Jenderal TNI

Saurip Kadi, Jakarta : Yayasan Obor Indonesia

Kusumohamidjojo, Budiono, Dr,1987.Hubungan Internasional Kerangka Studi Analitis, Jakarta:Binacipta Kasmir, 1999.Bank dan Lembaga Keuangan Lainnya, Jakarta: Rajawali Press

Kelana,Said.1996. Teory Ekonomi Makro, Jakarta:Pt. Raja Grafindo Persada Kusumohamidjojo, Budiono, Dr, Hubungan Internasional Kerangka Studi Analitis, Jakarta,Binacipta Lebang, Tomi,2010. Sahabat lama era Baru, Jakarta: Grasindo 
Mas'oed, Mohtar,1994. Disiplin dan Metodelogi Hubungan Internasional, Jakarta: LP3ES , 1994. Ekonomi-Politik Internasional dan Pembagunan, Yogyakarta : Pustaka Pelajar

Nopirin,1996. Ekonomi Moneter, Yogyakarta: BPFE-Yogyakarta

Odling, Jhon-Smee. 2004 IMF Working Paper The IMF and Russia in the 1990s. Washinton D.C. : International Moneter Fund

Pandjaitan,OE, d.k.k, 2010, Pedoman Penulisan Skripsi, Jakarta : FISIP UNTAG JAKARTA .

Saragih, Simon, 2008. Bangkitnya Rusia, Jakarta: Pt Kompas Media Nusantara

\section{Webite-Statement}

www.wikipedia.com

http://kamusbahasaindonesia.org

www.fsb.ru

www.imf.org

http://news.bbc.co.uk//onthisday/hi/dates/stories/october/4/newsid_2685000/2685115.stm

http://www.investor.co.id/home/subsidi-dan-haluan-ekonomi-indonesia/38965

Makalahdan Laporan

Monica Dian Adelina, Skripsi Sentralisasi Demokratik Vladimir Putin dalam Mengatasi Krisis

Ekonomi di Federasi Rusia, Universitas Indonesia, tahun 2009

Eustace Mullins, The \$ 5 Trillion Cold war hoax, The Phoenix Project. May 21, 1996. http://www.whale.to/b/mullins6.html.

Belajar dari Rusia Melunasi Hutang, Riau Pos, 28 Agustus,

2006.http//www.freelists.org/post/ppiindia-Belajar-dari-Rusia-Melunasi-Hutang-htm.

Official Russian State Custom Committee Statistics, 1994-2004. Foreign trade :of time.

Peter Isard oleh Dian Novikrisna, Revie Mata Kuliah Rezim Keuangan Internasional, , Globalization and the International Financial System: What' Wrong and What Can Be Done, (Cambridge:Cambridge University Press, 2005) Chapter(3), http://www.google.com/search?q=xa.yimg.com

Russian Federation Economic Outlook and Policy Challenges Odd Per Brekk Senior Resident Representative Spring 2012

Susanto Putjo Martono, Kompas, "Siapa penganti Putin”. 28 September,2007.

Http://www2.kompas.com/kompas-cetak/0709/28/ln/3870742,htm.

Thomas F. Remington, "Putin and Duma, Post-Soviet Affair", Vol. 17.No. 4, 2001. PP. 285-308

\section{Jurnal}

Ahmad Sujai, Glasnost, Membaca Jejak Putin, Vol.4 No.2, Oktober 2008-Maret 2009

Emelia Yustiningrum, Jurnal Penelitian Politik, Partai Politik Pemilu dan pemerintahan Rusia, Vol.1,

No. 1,2004

R.de Archellie, Glasnost, Pragmatisme Polotik luar Negeri Vladimir V. Putin, Vol 4. No.2, Oktober 2008-Maret 2009

Rodrik, Dani. Journal of Economic Literature. Vol. XLIV (December 2006), pp.

973-9 